Ssciendo Studia Anglica Posnaniensia 54s1 (2019): 337-355

doi: 10.2478/stap-2019-0016

\title{
CHANGE FROM ABOVE, LANGUAGE CONTACT, AND INDIVIDUAL CHANGE IN ÆLFRIC'S LINGUISTIC TERMINOLOGY
}

\author{
YEKATERINA YAKOVENKO ${ }^{1}$
}

\begin{abstract}
The paper focuses on linguistic terminology used by Ælfric $\left(10^{\text {th }} \mathrm{c}\right.$.) in his translation of an anonymous Latin grammar (Excerptiones de arte grammatica anglice) going back to Priscian and Donatus' works. Flfric's grammatical metalanguage, comprising loan words, semantic loans, loan translations, and periphrastic expressions created for explanatory purposes, is characterized by great diversity. A question arises whether these terms, remaining occasional, made any impact on the language system and can be thus evaluated as change from above.

The paper combines a traditional semantic, morphological, and functional description of Ælfric's terminology and its consideration within the frame of sociolinguistics; the analysis is supplemented by a cross-linguistic study of Ælfric's terms with remarks on other Germanic languages. The results achieved enable us to argue that Ælfric's linguistic terminology, being innovative, displays some features of change from above, arising from language contact and individual change.
\end{abstract}

Keywords: Change from above, language contact, metalanguage, loan words, semantic loans, loan translations, code-switching, terminology.

\section{Introduction}

\subsection{General remarks}

Vocabulary is known to be the part of a language most susceptible to outer influence. Most changes in vocabulary that are accounted for by extralinguistic causes (development of science and technology, social events, international contacts, etc.) take place irrespective of conscious choices and intentions.

1 Institute of Linguistics of the Russian Academy of Sciences, B. Kislovsky Per. 1, Bld. 1, 125009 Moscow, yakovenko_k@rambler.ru 
However, the history of English provides several examples of changes introduced by individuals aiming at filling gaps in the vocabulary of the time or verbalizing already existing notions in a new way. Though authors' coinages, being quite often far from successful, remain on the periphery of this vocabulary, they reveal the word formation potential of the language system. It is problematic whether they make any impact on the language and should be described as change from above.

The notion of change from above was introduced by William Labov (2006 [1966]), who investigated it at length in the area of sociolinguistics. Opposing change from above to change from below, Labov sees in changes from above linguistic processes: "A change from above is exerted by overt pressure upon formal styles of speech, with results that are sporadic or unsystematic from a linguistic point of view. A change from below occurs below the level of conscious attention, affecting all members of a word class..." (Labov 2006 [1966]: 240). Unlike change from below, change from above implies conscious awareness of the speakers (Labov 2006 [1966]: 346, 349). As Labov points out, "change from above is clearly the result of social factors operating upon language. We usually recognize change from above by the fact that it involves high-prestige features, which spread downward from the social class of highest status. But this is not a sufficient criterion, because it is possible for the upper class to be an originating center of change within the system. Change from above (the linguistic system) implies that the new element is imported from some external language or dialect. [...] Changes from above usually involve superficial and isolated features of language" (Labov 2010: 185).

Sharing Labov's ideas, Ronald Wardhaugh stresses that change from above "involves issues of prestige" (2010: 216). He points out that change from above is not necessarily initiated within the highest social group in society and usually begins in slightly lower groups.

Labov's theory has been challenged by other conceptions of change: for instance, Raymond Hickey, offering a model of lexical diffusion, points out that one of its most relevant issues is what words are first subject to change. He claims that "lexical diffusion can be seen to operate according to the status of the words which form a possible input to a change" (Hickey 1999: 235). Sylvie Dubois and Barbara Horvath identify change from above and change from below as adoption and innovation, respectively, emphasizing the social character of the former and the linguistic character of the latter (Dubois \& Horvath 1999: 302). James Milroy offers another dichotomy which differentiates change occurring within the language systems themselves and innovations introduced by speakers of languages (Milroy 1999: 23). In his opinion, change in language is made by speakers introducing innovations which may become changes under certain circumstances. This statement is of much relevance for our research: in Section 4 
of the paper the innovative character of Ælfric's linguistic activity will be demonstrated.

Addressing Ælfric's Grammar (Excerptiones de arte grammatica anglice), the paper provides a specific treatment of his grammatical terminology and its parallels in other Old and Modern Germanic languages. The question that concerns us is whether individual change arising from a written form of language contact can be generally regarded as change from above. The examination of this question will provide insight into the main problem of the paper - whether Ælfric's grammatical terms in particular can present evidence of language change from above or give an example of innovations able to develop into change from above.

In order to solve this problem, we combine a traditional semantic, morphological, and functional analysis of Ælfric's terms with their consideration in terms of sociolinguistics. This analysis will be reinforced by a cross-linguistic study of similar phenomena of Old and Modern Germanic languages (Old English, Old High German, Old Icelandic, Modern English, and Modern Icelandic) aiming at revealing common and unique features of Ælfric's terms. The investigation of Ælfric's terminology is preceded by a short review of approaches to Ælfric's works.

\subsection{Approaches to Ælfric's Grammar in modern studies}

Ælfric (c. 955 - c. 1010) is generally recognized as one of the most influential late Anglo-Saxon authors. His vast legacy comprises two series of Homilies, each containing 40 texts, the Lives of the Saints, written partly in alliterative prose, a partial translation of the Old Testament, called the Hexateuch, and a set of three books aimed at learning Latin: Grammar, Glossary, and Colloquy. ${ }^{2}$ Ælfric's identity, the character of his writings, and their historical background are investigated at length in a number of works (White 1898, Gneuss 2009, Hill 2009, Magennis 2009, Stephenson 2015, among many others). Ælfric is acknowledged as "a prolific and wide-ranging author, an accomplished stylist, and arguably the most significant intellectual figure of his age" (Magennis \& Swan 2009: 1).

Ælfric's Grammar holds a special place in his vast legacy, having attracted academic attention since its first full edition, prepared by Julius Zupitza, which appeared in 1880. It was generally believed that Ælfric's translation was based on Donatus' Ars maior and Ars minor and Priscian's Institutiones grammaticae and De Institutione de nomine et pronomine et verbo (Hunt 1991); however, a more recent investigation carried out by David Porter shows that it goes back to Excerptiones de Prisciano, an abridged anonymous grammar, while Donatus and Priscian's works should be regarded as ultimate sources (Porter 2002).

$2 \quad$ Ælfric’s Colloquy was written in Latin; its Old English translation is attributed to Ælfric Bata. 
Elfric's Grammar represents rather a free rendering of Latin grammar, followed by an explication in Old English. After the Benedictine Reform a book of this kind was quite necessary: acquisition of Latin through Latin grammatical terminology could not be effective (at least at an initial stage of studies) and the training required better tools than those that teachers of that time could offer. Introducing Old English grammatical terminology into the explanation, Ælfric facilitated learning Latin, preparing his students for more sophisticated works. As Thomas Hall states, "the pedagogical method he [Ælfric] has adopted in the Grammar rests on the foundation of his own training in Latin under Bishop Æthelwold, who is likewise known for having translated Latin texts into English for his own pupils and for instructing them in the rules of grammar" (Hall 2009: 197).

The semantic and structural variety of Ælfric's grammatical terms, as well as his pedagogical strategies, have made his work the object of numerous investigations. Former studies of the Grammar (Law 1987, 1993; Gneuss 1990, 2009; Kleiner 1985; Menzer 1999, 2004, and others) described it mainly within the frame of history of linguistics and/or contrastive text studies, which was very important, but certainly not sufficient. However, a paper by Edna Williams (Williams 1958) and, among recent publications, those by Fabienne Toupin and Martha Mensah (Mensah \& Toupin 2005; Toupin 2009), Don Chapman (Chapman 2010), and particularly Dieter Kastovsky (1992, 2011) shed light on the translational techniques used by Ælfric in his Grammar. Ælfric's approach is also mentioned in works on code-switching in Old English (Timofeeva 2010; Schendl 2011, 2017).

Ælfric's work, due to its outstanding value, requires complex, probably interdisciplinary investigation which would reveal new aspects of the scholar's linguistic activity. We hope that our attempt to analyse Ælfric's terminology from different points of view, as shown below, will contribute to a deeper understanding of its role in language change.

\section{2. Ælfric's terms: Semantics, morphology, functions}

\subsection{Inventory of terms used by Ælfric}

Linguistic terms used by Ælfric display remarkable diversity as for their origin, morphology, and correlation with Latin terms, as stated by several researchers (Kleiner 1985, Gneuss 2009, Chapman 2010, among others). The taxonomy of Ælfric's terms suggested by Dieter Kastovsky $(1992,2011)$ is based on semantic and morphological criteria and includes such types of loans as loans proper, semantic loans, loan translations, and loan-creations. Kastovsky differentiates cases when (a) "the meaning of some lexical item of the donor language 
influences the meaning of an already existing native word by being added to it (semantic loan)" and "(b) the meaning of some lexical item of the donor language is translated into a complex expression consisting of linguistic material of the receptor language" (Kastovsky 1992: 300). The latter case is further subdivided by Kastovsky into loan translations strictly following the original and loancreations differing morphologically from the original.

Claiming that Latin terms embedded in the text cannot be borrowings yet, we offer a somewhat different classification of Ælfric's words, first suggesting a dichotomy of Latin elements and those built on English material, with a further subdivision of the latter: ${ }^{3}$

I. Single-word code-switches: vocales, consonantes, praesens, praeteritum, etc. (i.e., all Latin terms appearing in the Grammar). ${ }^{4}$

II. Words displaying phenomena different from code-switching:

1. Semantic loans - transfers of meaning on already existing native words: cynn (Lat. genus) "gender", hiw (Lat. species) "kind, species, form, aspect, figure", hād (Lat. persona) "person", sweg (Lat. accentus) "accent", andwerd (Lat. praesens) "present" etc.

2. Loan translations (calques, or morpheme-for-morpheme translations): Lat. vocales "vowels" - clypjendlice (literally: "those that sound, cling"), Lat. consonantes "consonants" - samod sweegende (literally: "those that sound (make a noise) together [with other sounds]"), Lat. participium "participle" - doel nimend (literally: "taking part"), Lat. significatio "meaning" getacnung (literally: "de-noting, de-signing"), Lat. pluralis "plural" manigfeald (literally: "manifold"), Lat. infinitivus "infinitive" ungeendigendlīe (literally: "endless, going on without end"), Lat. accusativus "accusative" - wrēgendlīc (literally: "accusing") and many others.

3. Periphrastic expressions (loan-creations, in Kastovsky's terminology): Lat. derivativus "derivative" - ða ðе cumað of oðrum namum (literally: "what comes from another word"), Lat. (nomina) collectiva "collective (names)" - pā getācniað on ānfealdum getele mycele meniu (literally: "those that express large quantity in singular").

3 In fact, our point of view is very close to that of Fabienne Toupin (2009) arguing that borrowing and neology are two methods used by Ælfric to introduce Latin grammar to his oblates (and also two main ways of enriching the word-stock of the language). However, we object to identifying Latin terms occasionally appearing in Ælfric's work as borrowings (see above).

4 The term "single-word code-switching" is used, for instance, by Shana Poplack (1980), François Grosjean (1995), Jeanine Treffers-Daller (2005), and other researchers. 
The full list of Ælfric's terms is much larger. It comprises, according to Chapman's estimations, over two hundred words and expressions (Chapman 2010: 422-423). Semantic loans and loan translations appear to be the most common type as they contribute to comprehension and create a new text (see below in 2.2.). Periphrastic expressions serve the same purposes, but, amplifying the explanation, they may be inconvenient for syntactic reasons. Extensive use of semantic loans, loan translations, and periphrastic expressions does not lead to the supplantation of loan words: as Edna Williams estimates, in Ælfric's Grammar there are more than 940 occurrences of terms formed by native words, over 1400 occurrences of Latin terms, and nearly 250 contexts where a Latin word and its native equivalent are used simultaneously (Williams 1958: 461-462).

Considering the semantics of words used by Ælfric allows us to single out terms of phonetics, grammar (morphology) and, to a smaller extent, rhetoric. These terms certainly do not give a complete idea of these branches, hardly differentiated in ancient and medieval grammars; rather, they serve to express particular concepts appearing in the source texts. The phonetic terms used by Elfric refer to types of sounds and some of their articulatory features, mainly sonority; accent (swe g) is mentioned as an element of prosody. Grammar terms comprising loan words, semantic loans, and loan translations are used to nominate grammar categories and particular grammar meanings (case, number, gender, tense, aspect, etc.) proper to one or several parts of speech. Most phonetic and grammatical notions find double (Latin and Old English) expression in Ælfric's Grammar (consonantes and samod swēgende for "consonants", participium and doel nimend for "participle", praepositio and foresetnys for "preposition", interrogativus and āxigendlīc for "interrogative", subiunctivum and underðēodendlīc for "subjunctive", etc.). Notions of rhetoric are rendered by means of Latin words only (barbarismus, solecismus, metaplasmus, tropi, etc.).

The morphological structure of Ælfric's terms depends on their category in the proposed classification: most semantic loans are simplexes (see examples above); loan translations imitate the structure of the corresponding Latin words, though revealing in some cases morphological non-identity with the word in the source text (getacnung ( $<$ tācn "sign, token", a derivative) - Lat. significatio (a derivative going back to a verbal compound: significatio $<$ significare $<$ signum + facere); manigfeald (a compound) - Lat. pluralis (a derivative of plures, comparative of multum)). Loan translations are represented by mainly nominal and adjectival derivatives, and compounds are built according to productive Old English patterns. Prefixal word formation seems to be rare (gemet "mood; metre (in versification)" is morphologically a prefixed derivative, but formed as a semantic loan); suffixal derivation is quite common (werlīc "masculine", wîflìc "feminine", tīdlīc "temporal") and often combined with prefixation (geendung "inflexion", bebēodendlīc "imperative", gebìdednys "declension", gedèodnys "conjugation", 
etc.). Most compounds are formed by the mere juxtaposition of nominal, adjectival, and adverbial stems (stafgefég "syllable", (namena) ordfruma "etymology", forðgewiten "past" (tense), etc.). Generally, Ælfric's terms are formed in accordance with word formation patterns represented in Old English.

\section{2. Ælfric's strategies for incorporating terms in his text}

Alongside various techniques of translating, Ælfric uses different principles of incorporating terms in his text. As his strategies are exposed in detail in several works (Gneuss 1990, Menzer 2004, Chapman 2010, and others), we think it necessary to focus on the most typical ways of representing grammatical notions in Ælfric's Grammar in terms of structural-semantic and sociolinguistic approaches:

1. Insertion of Latin terms and their explanation by means of semantic loans, loan translations, or periphrastic expressions (the combination of intrasentential code-switching and loan-translations) is undoubtedly the strategy Ælfric uses most often:

(1) Soðlice on lǣdensprǣce synd preo and twentig stafa: a, b, c, d, e, f, g, h, i, k, l, m, n, o, p, q, r, s, t, u, x, y, z. of ðām syndon fîf vocales, pāt synd clypjendlīce : a, e, i, o, u. ðas fîf stafas aetēowjað heora naman purh hī sylfe and būtan ðām stafum ne mæg nān word bēon āwriten, and for đ̄i hī synd qvinqve vocales gehātene (Zupitza 1880: 5, italics is ours - Yekaterina Yakovenko).

"There are twenty-three letters in Latin: a, b, c, d, e, f, g, h, i, k, l, m, n, o, p, q, $\mathrm{r}, \mathrm{s}, \mathrm{t}, \mathrm{u}, \mathrm{x}, \mathrm{y}, \mathrm{z}$. Five of them are vowels (literally: sounding): a, e, i, o, u. These five letters manifest their names by themselves. No word can be written without them and therefore they are called five vowels" (the translation is hereinafter ours).

Here also belong cases of extrasentential code-switching ${ }^{5}$ (a Latin quotation is followed by a translation):

(2) Duo participia veniunt a verbo activo twegen dāelas, ðe synd gecweðene dēel nimende, cumað of ðam dōedlīcum worde (Zupitza 1880: 152).

"Duo participia veniunt a verbo activo two parts, that is, two so called participles, come out of the doing verb (the verb in the Active Voice)".

The terms "intrasentential code-switching" (code-switching occurring within a sentence or a clause) and "extrasentential code-switching" (code-switching having the structure of a sentence or a clause itself) are widely used and thus not discussed in this paper. Their more detailed consideration can be found, for instance, in Poplack (1980) and Treffers-Daller (2005). 
(3) verbum is word, and word getacnað weorc, oððe ðrowunge oððe gepafunge. [...] advervium is wordes gefêra, forðan de hē næfd nāne fulfremednysse, butan hē mid ðām worde bēo. [...] participium ys dēel nimend. hē nymð ānne d̄̄l of naman and oðderne of worde, of naman he nymð casus, pæt is, declining, and of worde hē nymð tide and getācnunge, of him bām hē nymơ getel and hīw (Zupitza 1880: 9).

"Verbum is a verb, and a verb denotes an action, suffering or permission. [...] Adverbium is the verb's companion, it expresses completion only when it accompanies the verb. [...] Participium is what takes part. It takes one part from the noun and the other from the verb. It takes from the noun case, that is, declension, and it takes from the verb tense and meaning, and it takes from them both number and form".

The passage above is of much interest as one can observe here, within a relatively small space, all possible ways of expressing grammar notions: Latin terms (verbum, participium, etc.), semantic loans (tīd, getel (getcel)), the use of loan

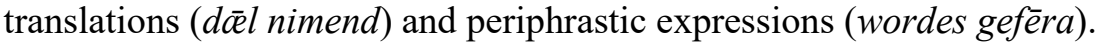

2. Further use of either Latin terms, once explained in Old English, or native words also occurs frequently:

(4) pā ōðre nigon consonantes synd gecweðene mvtae, pæt synd dumbe. (Zupitza 1880: 6).

"The other nine consonantes are called mutae, that is, mute".

The term consonantes, once introduced and explained by Ælfric (Zupitza 1880: 5) (see (1)), is no longer commented on and is used as a single code-switch afterwards.

3. A macaronic text representing successive code-switching, that is, an alternation of elements of the two languages:

(5) $[\ldots]$ amo ic lufige [...] praeterito tempore inperfecto fordgewitenre tīde unfulfremedre amabam ic lufode, [...] tempore praeterito perfecto amavi ic lufode fulfremedlīce, [...] tempore praeterito plusquamperfecto amaveram ic lufode gefyrn, [...] futuro tempore on tōweardre tīde amabo ic lufige gyt tō dceg oððe tō merjen, [...] imperativo modo on bebēodendlīcum gemete [...] ama lufa $\partial \bar{u},[\ldots]$ subjunctive modo underðēodendlīcum gemete tempore praesenti cum amem ponne ic nū lufige (Zupitza 1880: 130-132). ${ }^{6}$

6 For the sake of space, full verbal paradigms quoted and translated by Ælfric are reduced to single examples. 
"Amo "I love", [...] praeterito tempore imperfect past tense not performed amabam "I loved", [...] tempore praeterito perfecto amavi "I loved completely", tempore praeterito plusquamperfecto amaveram "I loved before", [...], amabo futuro tempore the future tense "I still love today or I will love tomorrow", [... imperativo modo the Imperative Mood ama "love!", subjunctivo modo the Subjunctive Mood tempore praesenti "so that I love now".

(5) is one of the most complicated passages in Ælfric's Grammar as it presents a combination of intrasentential code-switching followed by a translation (e.g., Lat. imperativo modo- $\mathrm{OE}$ on bebēodendlīcum gemete), extrasentential code-switching displayed in clauses and also followed by a translation into Old English (e.g., Lat. amavi - OE ic lufode fulfremedlice), semantic loans (Lat. tempus - OE tīd, Lat. modus - OE gemet), and loan translations (Lat. imperativus - OE bebēodendlīe, Lat. subjunctivus - OE underðēodendlīc). It is undoubtedly a brilliant interpretation of the Latin verb system by means of Old English, taking into account that the Old English verb had only two tenses - the present and the past. Ælfric's task could have been facilitated by the use of analytic constructions spreading at the end of the Old English period and expressing various grammatical meanings (continuity, futurity, passivity, completion of action, etc.). However, he preferred simple forms accompanied by lexical tense markers, mainly adverbs and prepositional phrases (fulfremedlīce, gefyrn, tō doeg, tō merjen, etc.). It can be accounted for by the fact that Ælfric's main aim was explanatory and not contrastive.

These as well as many other examples demonstrate the character of Ælfric's terms and the ways they function. Using various strategies, Elfric created a new type of text which can probably be determined as an amplified explanatory translation. Being in fact not bilingual, it gives, alongside with a detailed description of Latin, an implicit insight into the system of Old English (grammatical categories of the main parts of speech, basics of word formation, etc.).

\section{A contrastive cross-linguistic analysis of Ælfric’s terms and strategies}

\subsection{Grammar terms in Old Germanic languages}

Despite being the only Latin grammar translated systematically into Old English, Ælfric's Grammar is not unique. Moreover, it justifies tendencies developing in medieval Europe - conservation of ancient cultural heritage and its adaptation to a new culture.

Seen from this point of view, Ælfric's linguistic terms must be studied together with analogous terms occurring in works on grammar, also philosophy and logic, appearing in Old Germanic languages in different parts of Europe. 
There is no evidence of Ælfric influencing the Anglo-Saxon writers of his period. Byrhferth, Ælfric's contemporary and the author of the famous Enchiridion ("Manual"), treats various issues, suggesting, in particular, a detailed description of figures of speech (Crawford 1929). It is noteworthy that his strategies for incorporating loanwords into his text and interpreting them are similar to those used by Ælfric:

(6) We gesetton on pissum enchiridion (pæt ys manualis on Lyden and handboc on Englisc) manega ping ymbe gerimcræft forpon we woldon pæt iunge men mihton pe leohtlicor pæt Lyden ongitan and wið ealre preostas ymbe pas ping pe rumlicor sprecan...

"We have set down in this enchiridion, that is manualis in Latin and manual in English, many things about the computus, because we wished that young men should be able the more easily to understand the Latin and speak with greater freedom to old priests about these things..." (Crawford 1929: 133).

Moreover, Byrhtferth's use of some terms of grammar and rhetoric displaying identity on Ælfric's terms ( hiw "figure (of speech)", anfeald getoel "singular", manigfeald getcel "plural", and others) makes us think that Ælfric's authorship of grammatical terminology is rather dubious. In any case, attributing the words in question to Ælfric, we can never be sure if he was the first to create or use them.

Notker's (c. 950 - 1022) rendering of the Latin translation of Aristotles' "De Interpretatione" in Old High German contains several linguistic issues that could only be discussed at that time in the frame of philosophy and rhetoric (correlation of sounds and letters, the essence of a sign, its conventional character, general meaning of parts of speech, assertion and negation, etc.). For example, characterizing the verb as a part of speech, Notkers writes (Latin and Old High German lines alternate in the following extract, as quoted):

(7) Uerbum autem est. quod consignificat tempus.

Uerbum ist. táz sáment actione. álde sáment passione. presens álde preteritum álde futurum tempus pezéichenet.

Cuius pars nihil extra significat.

Tés pars níeht túrh síh nebezéichenet Dico autem quoniam consignificat tempus.

I'h chido iz tempus pezéichenne. mit ánderro bezéichennissedo (Notker 1848:

469).

"The verb is what [also] means time.

The verb is what means action, or feeling, [it means] present, or past, or future tense.

No part of it means anything else. 
No part of it means anything by itself. I say it means time.

I say it means time, together with another sign (literally: another thing that denotes)."

The translation is evidently an amplification of the Latin version. Far from working out new grammatical terminology, Notker applies other techniques of rendering Latin terms. Old High German having no terms for denoting tenses, Notker has to use Latin words (verbum, tempus, presens, preteritum, futurum) and incorporate them into the text. This is not the only possible way to render Latin terms: the so called "St Gall Schularbeit" discovered in St Gall library and dating back to approximately the same period $\left(11^{\text {th }} \mathrm{c}\right.$.) is an anonymous grammar exercise where the Latin names of parts of speech alternate with their Old High German equivalents. The latter, being either simplexes or loan translations, bear a surprising resemblance to Ælfric's terms:

(8) Nomen. námo. Pronomen. fúredáz nomen.

Verbum. uuórt. Aduerbium. zúozedé

mo uerbo. Participium téilnémunga.

Coniunctio geuúgeda. Preposicio. fúre

sézeda. Interiectio. úndéruuerf (quoted and interpreted at length by Anna Grotans (Grotans 2006: 140ff)).

Old Icelandic Grammatical Treatises are, unlike the works of Ælfric and Notker, original compositions of the $13^{\text {th }} \mathrm{c}$., devoted to Icelandic phonology, spelling, general problems of grammar, and figures of speech. The vocabulary and style of the Grammatical Treatises are not homogeneous. The First Grammatical Treatise, treating Icelandic phonology and phonemic oppositions, contains comparatively few terms (Benediktsson 1972). The Second Grammatical Treatise deals with issues of orthography (Raschellà 1982); its wording is close to that of the First Treatise. The terminology of the Fourth Grammatical Treatise, treating issues of poetics, is largely Latin or latinized Greek:

(9) PROTHESEOS PARALOGE verðr bá er önnur prepositio stendr par er önnur ætti viðkæmiliga að vera (The Fourth Grammatical Treatise 2014: 2)

"PROTHESEOS PARALANGE occurs when one preposition is used where another would have been appropriate" (2014: 3)

Of all these, the Third Grammatical Treatise, especially its second part going back to Priscian, presents more interest for us as the loan translations used in it resemble those introduced by Ælfric: 
(10) Meistari Priscianus tellr átta parta málsgreinar, pessa: nafn ok fornafn, orð ok viðrorð, hluttekníng, samtengíng, fyrirsetníng ok meðalorpníng [...]. Nafn er lutr málsgreinar, sá er veitir eiginligan eðr sameiginlogan hvíligleik hverjum líkama, hann er æztr allra sagna [...].parnæst er orð, er skrýðir ok formerar nafnið, svá sem mynd efni, pvíat pat skýrir tilfelli nafns, gjörð eða píníng. Fornafn er sett í stað nafns... (Ólsen 1884: 90).

"Master Priscian singles out eight parts of speech, these are: noun and pronoun, verb and adverb, participle, conjunction, preposition, and interjection [...]. The noun is a part of speech that attributes to the object proper or common features, it is the principle of the vocabulary. Then comes the verb, it decorates and defines the noun, shows the noun accidences, action or suffering. The pronoun is a substitute for the noun..."

As one can see, the morphology of Ælfric's terms naming parts of speech and their Old High German and Old Icelandic counterparts is in most cases similar (to say nothing of their common roots):

Lat. nomen - Old English (OE) nama, Old High German (OHG) námo, Old Icelandic (OIc) nafn;

Lat. pronomen - OE speliend ðces naman, OHG fúredáz nomen, OIc fornafn;

Lat. participium - OE dēl nimend, OHG téilnémunga, OIc hluttekning $(<$ hluti "part" + taka "to take");

Lat. adverbium - OE gefera wordes, $\mathrm{OHG}$ zúozedémo uerbo, OIc viðrorð (unlike its Old English and Old High German counterparts, the Old Icelandic term is a compound, meaning literally "with-verb" or "by-verb");

Lat. conjunctio - OE gepēodnys, OHG geuúgeda (literally: “joining”), OIc samtenging (< saman "together" + toga "to draw");

Lat. praepositio - OE foresetnyss, OHG fúre sézeda, OIc fyrirsetníng;

Lat. interjectio - OE betwuxālegednys, OHG úndéruuerf, OIc meðalorpníng (literally: "what is put (inserted, cast) between words)".

The fact that Ælfric, Notker, "St Gall Schularbeit", and the Old Icelandic Grammatical Treatises prefer practically the same ways of introducing Latin terminology (either retaining Latin words or using semantic loans/loan translations instead) is accounted for by the identical responses of the authors to their language-contact situations. An extensive use of semantic loans and loan translations forming the greater part of linguistic metalanguage in Old Germanic languages shows that it might be a reaction to the influence of a language having prestige at that period, that being, Latin. 
3.2. Terms created by Ælfric and their counterparts in modern Germanic languages

Contrasting linguistic terms introduced by Ælfric and their counterparts in modern Germanic languages (English, German, and Icelandic) reveals the affinity of their motivation and (often) morphology, though their origin may be different. These similarities and differences are shown in Table 1 below, offering a selection of a few of Ælfric's terms and their modern English, German, and Icelandic equivalents:

Table 1. A correlation of some linguistic terms introduced by Ælfric and their counterparts in modern Germanic languages (English, German, and Icelandic):

\begin{tabular}{|c|c|c|c|}
\hline Anglo-Saxon & Modern English & Modern German & Modern Icelandic \\
\hline nama & name & $\begin{array}{l}\text { Nennwort, } \\
\text { Substantiv }\end{array}$ & nafnorð \\
\hline $\begin{array}{l}\text { ðes naman } \\
\text { spelzend }\end{array}$ & pronoun & Fürwort, Pronomen & fornafn \\
\hline word & verb & $\begin{array}{c}\text { Verb, Zeitwort, } \\
\text { Tuwort (obs.) }\end{array}$ & sagnorð \\
\hline foresetnys & preposition & $\begin{array}{c}\text { Vorwort (obs.), } \\
\text { Präposition }\end{array}$ & forsetning \\
\hline stemn & voice & $\begin{array}{l}\text { Genus verbi, } \\
\text { Aktionsart, } \\
\text { Handlungsart } \\
\end{array}$ & mynd \\
\hline gemet & $\operatorname{mood}$ & $\begin{array}{c}\text { Aussageweise, } \\
\text { Modus }\end{array}$ & háttur \\
\hline $\begin{array}{l}\text { bebēodendlīc } \\
\text { gemet }\end{array}$ & $\begin{array}{l}\text { the Imperative } \\
\text { Mood }\end{array}$ & $\begin{array}{c}\text { Befehlsform, } \\
\text { Imperativ }\end{array}$ & $\begin{array}{c}\text { boðháttur } \\
\text { (< boð “order”) }\end{array}$ \\
\hline $\begin{array}{l}\text { underðēodendlīc } \\
\text { gemet }\end{array}$ & $\begin{array}{c}\text { the Subjunctive } \\
\text { Mood }\end{array}$ & $\begin{array}{l}\text { Bedingungsform, } \\
\text { Möglichkeitsform, } \\
\text { Konjunktiv }\end{array}$ & $\begin{array}{l}\text { viðtengingarháttur } \\
\text { (<við "at, by"+ } \\
\text { tengja “connect, put } \\
\text { up" + háttur } \\
\text { "mood") }\end{array}$ \\
\hline
\end{tabular}

Generally, modern English linguistic terminology is nearly completely borrowed. As for German grammatical terminology, it comprises Latin loans and words formed from Latin stems as well as some obsolete loan translations. Icelandic linguistic terms, being semantic loans or loan translations, display a certain 
morphological similarity with Ælfric's terms. This similarity is accounted for by the choice of the same translation techniques and affinity of the Old English and Icelandic lexical and morphological systems. Moreover, one can claim that the preference for semantic loans and loan translations demonstrates the resistance of the language or an author to foreign terminology, as stated in 3.1.

In modern English, too, the excess of Romance (Latin and French) loan words caused sometimes a similar reaction, resulting in occasional derivation from native stems. Individual manifestations of language purism are not seldom, and they affect linguistic terminology as well. William Barnes (1801-1886), a British scholar, priest, and poet, protested vividly against the abuse of foreign words and, developing a purist doctrine, used some occasional terms in his works (e.g., pure breathsounds "vowels" and clipped breathsounds "consonants" (Barnes 1854: $1 \mathrm{ff}$. )). Some of his coinages have the same semantics and (often) the same morphemic structure as that of Ælfric's terms: nama "noun” (Ælfric) - name-word (Barnes), getel "number" (Ælfric) - tale (Barnes), etc. Another project, called "The Anglish Moot", does not refer to Barnes but takes up some of his ideas, calling for adversary word-formation on the basis of native stems and affixes. Words coined in "Anglish" imitate to some extent Ælfric's terms and sound Old English in general: tung, speech "language", rune, bookstave "letter (character)", clipend "vowel", withloud, samedswaying, sameswaying "consonant", twisound "diphthong", nameword "noun", deedword, workword "verb", byname, forename "pronoun", byword "adverb", foreput, foresetness "preposition", fall "case", timeshape "tense" and others (The Anglish Moot, https://anglish.miraheze.org). These are only occasional names and we are far from seeing in them Ælfric's influence on any types of Modern English linguistic terminology.

\section{Discussion}

Undertaking a grammatical work, Ælfric must have been quite aware of the complexity of the task. It was to be neither a glossed Latin grammar nor a list of paradigms. Those getting acquainted with Ælfric's Grammar were supposed to know the basics of Latin in order to get a deeper understanding of Latin grammar. Ælfric had to keep a balance between plain explanation and scholarly reasoning. Though this balance was shifted to this side or the other more than once, Ælfric's book is characterised by precise and transparent language, consistency, and cohesion.

Exploring Ælfric's role in English culture, we must distinguish the value of his Grammar and that of his terms. The former is undoubted: the Grammar, as well as other early original and translated grammars in Old Germanic languages, displays an ability to render the linguistic thought by new means. Kenneth Sisam's assertion that "no other book in Anglo-Saxon approaches it in the number 
of copies that survive" (Sisam 1953: 301) is acknowledged, though the exact number of the extant copies of Ælfric's Grammar is discussed, estimated as fifteen (Hall 2009: 197-198; Chapman 2010: 421) or sixteen (Kleist 2009: 391). In any case, the number of the surviving copies makes the Grammar "one of the most widely attested works of any kind in Old English" (Hall 2009: 197-198).

Having circulated in England up to the $12^{\text {th }} \mathrm{c}$., Ælfric's Grammar went out of use. Then, after several centuries of being lost, it regained new popularity certainly not as a teaching aid, but as an Old English record and testimony of the linguistic thought in the Anglo-Saxon period. As Helmut Gneuss states (2005: 246ff), it was included in William Somner's Old English-Latin Dictionarium (1659) and Elizabeth Elstob's Rudiments of Grammar for the English-Saxon Tongue (1715), long before its first critical edition appeared in 1880 (Zupitza 1880).

The value of Ælfric's terms can still be argued. On the one hand, elaborating grammatical terminology and introducing it into the text was an urgent issue: as Olga Timofeeva (2010) states in her research, in the late Anglo-Saxon period Latin-English contacts were weakened and the knowledge of Latin the clergy could have was evidently insufficient. Helmut Gneuss points out that Latin grammars as such were "either insufficiently comprehensive (apart from pedagogical shortcomings) or else were too ambitious and too loaded with detail, such as the Institutiones Grammaticae of Priscian" (Gneuss 2009: 23).

On the other hand, one cannot say that the use of terms suggested by Ælfric was extensive. Most of them were never used beyond the Grammar; in fact, "there is no written evidence for the application of grammatical knowledge to the vernacular in the first Anglo-Saxon period" (Gneuss 1990: 10). Sharing Gneuss' opinion, Vivien Law claims that Ælfric's grammatical terms "function as glosses to the technical vocabulary of Latin, an aid to the student in mastering the terminology that he would need for further studies in Latin" (Law 1987: 63).

Nevertheless, Ælfric's terms were more than tools used for explanatory purposes or examples of occasional coinage. Illustrating various techniques of translation and giving evidence of semantic and word formation processes, they contributed, at least in their period, to the growth of Old English vocabulary. Even if they were ousted later by other terms, the very attempt was valuable indeed.

Returning to the main question of this paper - whether Ælfric's terminology conforms to the criteria of change from above - we argue that this problem is to be considered from the point of view of both sociolinguistics and structural linguistics.

From the point of view of sociolinguistics, Ælfric's words had all the prerequisites for development into terms. They were created in the cultured milieu, the Anglo-Saxon clergy being the most educated social group which provided cross-linguistic contact. Ælfric's terms resulted from contact of a less 
prestigious language with a more prestigious one. Moreover, appearing in a prescriptive work, they were imposed rather than diffused.

From the point of view of structural linguistics, their creation is quite justified. Semantically (and also culturally), Ælfric's terms are undoubtedly necessary as they form a vast lexical layer (rather, a terminological system) serving to raise the level of scholarly knowledge. Morphologically, Ælfric's words (unless they represent code-switching) conform to the structure of Old English and utilise its word formation tendencies. Functionally (and also pedagogically and translationally), the usage of such words seems appropriate whatever strategy of introducing concepts of another culture (code-switching, semantic transfers, calques, etc.) is accepted by the author and whatever way of their incorporation in the text is preferred. Balancing between semantic loans/loan translations and code-switching, Ælfric demonstrates in fact two translational tendencies - those of domestication and foreignization - that developed later in translation practice. ${ }^{7}$

Last but not least, the effectivity of Ælfric's choices and strategies is confirmed by similar terminology in cognate languages, both old and modern ones. It is evident that under other circumstances (that is, but for the Norman Conquest and the following substitution of a considerable part of Old English vocabulary by French and Latin loans) words suggested by Ælfric could have developed into full terms, remaining in the language system.

In this respect, it seems that the written form of language contact can display, in particular, an elaboration of terminology in a particular domain contributing to knowledge transfer. However, the absence of the widespread use of these terms does not allow us to identify Ælfric's terms as a case of change from above. Ælfric's terms are rather innovations that manifest semantic, word formation, and other features of Old English.

\section{Conclusion}

In spite of the fact that Ælfric's terms are innovations displaying individual efforts, their value should not be underrated.

First of all, even if most terms offered by Ælfric remain hapax legomena, they reflect the potential of the Old English lexical system. In this respect any new coinages are of much value as they serve the nomination of new objects and domains.

The terms domestication and foreignization, denoting two opposite translation strategies making the translation conform to the target language and culture or keeping to the semantic and structural organization of the source text - are often attributed to Lawrence Venuti (Venuti 1995, 1998). However, Venuti was not the first to use them and the problem of translation strategies had been largely discussed before. 
Secondly, Ælfric's terms, appearing in a prescriptive work, are more than individual usages. Translated or reshaped by Ælfric in the way they could be understood by Latin learners and used by them in their studies, they are intended for public use; numerous copies of Ælfric's Grammar are evidence of its influence.

Thirdly, the similarity displayed between Ælfric's terms and their Modern Icelandic and (partly) German equivalents confirms the fact that terminology formed mainly by semantic loans and occasional formations is able to develop into a part of the vocabulary, unless hindered by other terminologies.

Therefore, although most of Ælfric's terms were replaced in later periods, his linguistic terminology is a case where many prerequisites of change from above based on language contact and individual change are observed.

\section{REFERENCES}

Anderson, George K. 1962. The literature of the Anglo-Saxons. Princeton, NJ: Princeton University Press.

The Anglish Moot. https://anglish.miraheze.org (accessed 10 August 2019).

Barnes, William. 1854. A philological grammar, grounded upon English, and formed from a comparison of more than sixty languages. Being an introduction to the science of grammar and a help to grammars of all languages, especially English, Latin and Greek.. London: John Russell Smith.

Benediktsson, Hreinn (ed.). 1972. The First Grammatical Treatise: Introduction, text, notes, translation, vocabulary, facsimiles. Publications in Linguistics. Reykjavík: Institute of Nordic Linguistics.

Chapman, Don. 2010. Uterque lingua / Agðer gereord: Ælfric's grammatical vocabulary and the Winchester tradition. Journal of English and Germanic Philology 109(4). 421-445. DOI: 10.1353/egp.2010.0011

Crawford, Samuel John. (ed.). 1929. Byrhtferth's Manual with an introduction, translation, sources, vocabulary, glossary of technical terms, appendices and seventeen plates. Vol. 1: Text, translation, sources and appendices. London: Oxford University Press.

Dubois, Sylvie \& Barbara Horvath. 1999. When the music changes, you change too: Gender and language change in Cajun English. Language Variation and Change 11(3). 287-313. DOI: $10.1017 / \mathrm{S} 0954394599113036$

Gneuss, Helmut. 1990. The study of language in Anglo-Saxon England. Bulletin of the John Rylands Library 72(1). 3-32.

Gneuss, Helmut. 2005. The first edition of the source of Ælfric's Grammar. Anglia 123( 2). 246259. DOI: $10.1515 /$ ANGL.2005.246

Gneuss, Helmut. 2009. Alfric of Eynsham: His life, times, and writings. Kalamazoo, MI: Medieval Institute Publications, Western Michigan University.

Grosjean, François. 1995. A psycholinguistic approach to code-switching: The recognition of guest words by bilinguals. In Lesley Milroy \& Pieter Muysken (eds), One speaker, two 
languages: Cross-disciplinary perspectives on code-switching, 259-275. Cambridge: Cambridge University Press. DOI: 10.1017/CBO9780511620867.012

Grotans, Anna A. 2006. Reading in medieval St. Gall. Cambridge: Cambridge University Press. DOI: $10.1017 / \mathrm{CBO} 9780511483301$

Hall, Thomas N. 2009. Ælfric as pedagogue. In Hugh Magennis \& Mary Swan (eds), A Companion to Alfric, 193-216. Leiden: Brill. DOI: 10.1163/ej.9789004176812.i-468.42

Hickey, Raymond. 1999. Developments and change in Dublin English. In Ernst Håkon Jahr (ed.), Language change: Advances in historical sociolinguistics, 209-244. Berlin \& New York: Mouton de Gruyter.

Hill, Joyce. 2009. Ælfric: His life and works. In Hugh Magennis \& Mary Swan (eds), A companion to Alfric, 35-65. Leiden: Brill. DOI: 10.1163/ej.9789004176812.i-468.14

Hunt, Tony. 1991. Teaching and learning Latin in thirteenth-century England. Vol. 1: Texts. Cambridge: D. S. Brewer.

Kastovsky, Dieter. 1992. Semantics and vocabulary. In Richard M. Hogg (ed.), The Cambridge history of the English language. Vol. 1. The beginnings to 1066, 290-408. Cambridge: Cambridge University Press. DOI: 10.1017/CHOL9780521264747.006

Kastovsky, Dieter. 2011. Translation techniques in the terminology of Ælfric's Grammar: Semantic loans, loan translations and word-formation. In Merja Kytö, John Scahill \& Harumi Tanabe (eds), Language change and bariation from Old English to Late Modern English: A festschrift for Minoji Akimoto, 163-174. Bern: Peter Lang Verlag.

Kleiner, Yuri. 1985. Latinskaya grammaticheskaya traditsiya v Anglii VII-XI vv. (Beda, Alkuin, Elfrik) [Latin grammar tradition in England in the $7-11^{\text {th }}$ centuries (Bede, Alcuin, Ælfric]. In Desnitskaya, A. V. \& S. D. Katsnelson (eds), Istoriya lingvisticheskikh uchenii. Srednevekovaya Evropa [History of linguistics. Medieval Europe], 62-76. Leningrad: Nauka.

Kleist, Aaron J. 2009. Assembling Ælfric: Reconstructing the rationale behind eleventh and twelfth-century compilations. In Hugh Magennis \& Mary Swan (eds), A Companion to Elfric, 369-398. Leiden: Brill. DOI: 10.1163/ej.9789004176812.i-468.85

Labov, William. 2006 [1966]. The social stratification of English in New York City (2nd edn). Cambridge: Cambridge University Press.

Labov, William. 2010. Principles of linguistic change. Vol. 3: Cognitive and cultural factors. Chichester: Wiley-Blackwell.

Law, Vivien. 1987. Anglo-Saxon England: Aelfric's «Excerptiones de arte grammatica anglice». Histoire. Épistémologie. Langage 9(1). 47-71.

Law, Vivien. 1993. The historiography of grammar in early Middle Ages. In Vivien Law (ed.), History of linguistic thought in early Middle Ages, 1-24. Amsterdam: John Benjamins Press.

Magennis, Hugh. 2009. Ælfric's scholarship. In Hugh Magennis \& Mary Swan (eds), A companion to Alfric, 5-34. Leiden: Brill. DOI: 10.1163/ej.9789004176812.i-468.8

Magennis, Hugh \& Mary Swan. 2009. Introduction. In Hugh Magennis \& Mary Swan (eds), A companion to Alfric, 1-3. Leiden: Brill. DOI: 10.1163/ej.9789004176812.i-468.7

Menzer, Melinda. 1999. Elfric's Grammar: Solving the problem of the English-language text. Neophilologus. 83(4). 637-652. DOI: 10.1023/A:1004536808737

Menzer, Melinda. 2004. Ælfric's English Grammar. The Journal of English and Germanic Philology 103(1). 106-124.

Milroy, James. 1999. Toward a speaker-based account of language change. In Ernst Håkon Jahr (ed.), Language change: Advances in historical sociolinguistics, 21-36. Berlin: Mouton de Gruyter. 
Notker. 1848. De Interpretatione, In Heinrich Hattemer (ed.), Notker's des Teutschen Werke (vol. 2), 465-526. St.Gallen: Scheitlin \& Zolikofer.

Ólsen, Björn M. 1884. Den tredje og fjcerde grammatiske afhandling i Snorres Edda. Copenhagen: Knudzon.

Poplack, Shana. 1980. "Sometimes I'll start a sentence in Spanish Y TERMINO EN ESPAÑOL: Toward a typology of code-switching". Linguistics 18(7-8). 581-618. DOI: 10.1515/ling.1980.18.7-8.581

Porter, David W. (ed). 2002. Excerptiones de Prisciano. The source for Alfric's Latin-Old English grammar. Cambridge: D. S. Brewer.

Raschellà, Fabrizio D. (ed.) 1982. The so-called Second Grammatical Treatise: An orthographic pattern of late thirteenth-century Icelandic. Florence: F. Le Monnier.

Ross, Margaret Clunies \& Jonas Wellendorf (eds). 2014. The Fourth Grammatical Treatise. London University College: Viking Society for Northern Research.

Schendl, Herbert. 2011. Beyond boundaries: Code-switching in the leases of Oswald of Worcester. In Herbert Schendl \& Laura Wright (eds), Code-switching in early England, 47-94. Berlin: De Gruyter. DOI: 10.1515/9783110253368.47

Schendl, Herbert. 2017. Code-switching in Anglo-Saxon England: A corpus-based approach. In Päivi Pahta, Janne Skaffari \& Laura Wright (eds). Multilingual practices in language history. English and beyond, 39-60. Berlin: De Gruyter.

Sisam, Kenneth. 1953. Studies in the history of Old English literature. Oxford: Clarendon Press.

Stephenson, Rebecca. 2015. The politics of language: Byrhtferth, Alfric, and the multilingual identity of the Benedictine Reform. Toronto: University of Toronto Press.

Timofeeva, Olga. 2010. Anglo-Latin bilingualism before 1066: Prospects and limitations. In Alaric Hall, Olga Timofeeva, Ágnes Kiricsi \& Bethany Fox (eds), Interfaces between language and culture in medieval England: A festschrift for Matti Kilpiö, 1-36. Leiden: Brill. DOI: 10.1163/ej.9789004180116.i-340.5

Toupin, Fabienne. 2009. Exploring continuities and discontinuities between Ælfric's Grammar and its antique sources. Neophilologus 94(2). 333-352. DOI: 10.1007/s11061-009-9185-5

Toupin, Fabienne \& Marthe Mensah. 2005. La Grammaire d'Elfric: Traduction et commentaire linguistique. Paris: AMAES.

Treffers-Daller, Jeanine. 2005. Code switching/Sprachwechsel. In Ulrich Ammon, Norbert Dittmar, Klaus J. Mattheier \& Peter Trudgill (eds), Sociolinguistics: An International Handbook of the Science of Language and Society (vol. 2), 1469-1482. Berlin: De Gryuter.

Venuti, Lawrence. 1995. The translator's invisibility. New York, NY: Routledge.

Venuti, Lawrence. 1998. The scandals of translation: Towards an ethics of difference. London \& New York, NY: Routledge.

White, Caroline L. 1898. Alfric: A new study of his life and writings. Boston, MA, New York, NY \& London: Lamson, Wolffe and Co.

Wardhaugh, Ronald. 2010. An introduction to sociolinguistics (5th edn). Chichester: WileyBlackwell.

Williams, Edna Rees. 1958. Ælfric's grammatical terminology. PMLA 73(5). 453-462. DOI: $10.2307 / 460287$

Zupitza, Julius (ed.). 1880. AElfrics Grammatik und Glossar. Erste Ablteilung: Text und Variante. Berlin: Weidmannsche Buchhandlung. 